九州大学学術情報リポジトリ

Kyushu University Institutional Repository

Abundance of the Parasitoid Complex Associated with Liriomyza spp. (Diptera : Agromyzidae) on Vegetable Crops in Central and Southern Vietnam

Tran, Dang Hoa

Graduate School of Bioresource and Bioenvironmental Sciences, Kyushu University

Tran, Thi Thien An

Faculty of Agriculture, Nong Lam University

Konishi, Kazuhiko

National Agricultural Research Center for Hokkaido Region

Takagi, Masami

Faculty of Agriculture, Kyushu University

https://doi.org/10.5109/4720

出版情報: 九州大学大学院農学研究院紀要. 51 (1)，pp.115-120，2006-02-01. Faculty of Agriculture, Kyushu University

バージョン :

権利関係 : 


\title{
Abundance of the Parasitoid Complex Associated with Liriomyza spp. (Diptera : Agromyzidae) on Vegetable Crops in Central and Southern Vietnam
}

\author{
Dang Hoa TRAN ${ }^{1}$, Thi Thien An TRAN ${ }^{2}$, Kazuhiko KONISHI ${ }^{3}$ \\ and Masami TAKAGI*
}

\author{
Laboratory of Insect Natural Enemies, Division of Biological Control, Department of Applied Genetics \\ and Pest Management, Faculty of Agriculture, Kyushu University, \\ Fukuoka 812-8581, Japan \\ (Received October 26, 2005 and accepted November 16, 2005)
}

\begin{abstract}
Field survey was conducted in 45 major vegetable growing municipalities in 20 provinces of five regions of central and southern Vietnam during November 2003 - July 2004 with the aim of recording parasitoid species associating with Liriomyza leafminers and their relative abundance on vegetable crops. Sampling of leafminer-infested leaves from 14 vegetable crops yielded 18 species of hymenopteran parasitoids. Among them, Neochrysocharis beasleyi, N. okazakii, N. formosa and Asecodes delucchii were abundant species. The most abundant parasitoid species reared from the leafminers on tomato and yard-long bean was $N$. beasleyi. This species was the second most abundant on French bean. Neochrysocharis okazakii was a major parasitoid species of the leafminers on onion and leaf mustard. Neochrysocharis formosa was the most abundant species of leafminers on casaba melon. This species was also the second most abundant on yard-long bean, tomato and onion. Hemiptarsenus varicornis existed on every host plant, and the second most major species on casaba melon. The results suggest the importance of different species of parasitoids in vegetable integrated pest management.
\end{abstract}

\section{INTRODUCTION}

The genus Liriomyza contains more than 300 species which are widely distributed in the New and Old Worlds but, nonetheless, most occur naturally in the temperate regions (Parrella, 1987). Approximately 23 species of Liriomyza have been reported as being economically important, and five of these are polyphagous, i.e. Liriomyza sativae (Branchard), L. trifolii (Burgess), L. huidobrensis (Branchard), L. bryoniae (Kaltenbach) and Liriomyza strigata (Meigen) (Spencer, 1973). Several Liriomyza species have been established in Vietnam (Table 1), becoming major pests in vegetable growing areas. Andersen et al. (2002) reported a detailed mapping of Liriomyza leafminers within Vietnam. Based on the report, L. sativae was the dominant species in 27 provinces of the north and south regions, while $L$. huidobrensis was only found in the Lam Dong province at attitudes of $1000-1800 \mathrm{~m}$. Liriomyza trifolii has been reported from Ho Chi Minh City in the northeast south region by Tran (2000). The Asian species Liriomyza chinensis (Kato) has become a serious pest on onion fields in the whole country (Tran and Takagi, 2005).

Agromyzid leafminers are known to have rich nat-

1 Laboratory of Insect Natural Enemies, Division of Biological Control, Department of Applied Genetics and Pest Management, Faculty of Agriculture, Graduate School of Bioresource and Bioenvironmental Sciences, Kyushu University; Fukuoka 812-8581, Japan

2 Department of Plant Protection, Faculty of Agriculture, Nong Lam Univesrity, Ho Chi Minh City, Vietnam

${ }^{3}$ Entomology Laboratory, National Agricultural Research Center for Hokkaido Region, Sapporo 062-8555, Japan

* Corresponding author (E-mail: mtakagi@agr.kyushu-u.ac.jp) ural enemy communities. Over 40 species of parasitoids have been recovered worldwide from Liriomyza spp. (Waterhouse and Norris, 1987) including 27 species in Japan (Konishi, 1998), 14 species in China (Murphy and LaSalle, 1999; Chen et al., 2003), 11 species in Indonesia (Rauf et al., 2000), 8 species in Malaysia (Murphy and LaSalle, 1999). Abundant parasitoid species belong to the families of Eulophidae (e.g. Hemiptarsenus varicoris (Girault), Diglyphus isaea (Walker), Neochrysocharis formosa (Westwood), N. okazakii Kamijo, N. sp., Chrysocheris pentheus (Walker)), Eucoilidae (e.g. Gronotoma sp.), Braconidae (e.g. Opius sp.), and Pteromalidae (e.g. Halticoptera circulus (Walker)) (Konishi, 1998; LaSalle, 1999; Murphy and LaSalle, 1999; Rauf et al., 2000; Chen et al., 2003). These communities of parasitoids have been recognized for their potential contribution to the integrated pest management (IPM) of leafminers in both glasshouses and open fields (Waterhouse and Noris, 1987; Minkenberg, 1990).

Because of the rapid increase and spread of leafminers, growers in Vietnam have frequently applied large quantities of insecticides, including dimethoate, fenitrothion, phenthoate, trichlorfon, fenobucarb, permethrin, ethofenprox, cypermethrin, thiamethoxam, cartap and abamectin, some of which are evidently harmful for beneficial insects. Applications of broad spectrum insecticides have resulted in a decrease of parasitoid abundance in the vegetable fields and development of pesticide resistance within fly populations, followed by an increase in leafminer density (Oatman and Kennedy, 1976; Saito et al., 1996, Murphy and LaSalle, 1999, Johansen et al., 2003). To control these pests by non-chemical means, it is necessary to first determine the parasitoid composition and to identify key native 
Table 1. Liriomyza leafminers on vegetable crops in Vietnam

\begin{tabular}{|c|c|c|c|}
\hline Species & Location/region & Crop & References \\
\hline \multirow[t]{6}{*}{ L. sativae } & $\begin{array}{l}\text { Whole country ( } 27 \text { investigated } \\
\text { provinces) }\end{array}$ & $\begin{array}{l}\text { French bean, tomato, cucumber, pumpkin, } \\
\text { yard-long bean, mung bean, Chinese } \\
\text { mustard, white gourd, pak-choi cabbage, } \\
\text { lettuce, water melon }\end{array}$ & $\begin{array}{l}\text { Andersen et al., } \\
2002\end{array}$ \\
\hline & Red River Delta & $\begin{array}{l}\text { Mung bean, yard-long bean, pumpkin, } \\
\text { tomato, cucumber, Chinese cabbage }\end{array}$ & $\begin{array}{l}\text { Berit, } 2001 \\
\text { Grimstad, } 2004\end{array}$ \\
\hline & Red River Delta & Tomato, potato, cucumber, pumpkin, & $\mathrm{Ha}, 2001$ \\
\hline & Central Highland & & \\
\hline & Northeast South & & \\
\hline & Northeast South & Cucumber & Tran et al., 2005b \\
\hline L. huidobrensis & Central highland & $\begin{array}{l}\text { Potato, garden pea, French bean, } \\
\text { cucumber, mung bean, green bean, tomato, } \\
\text { onion, lettuce }\end{array}$ & $\begin{array}{l}\text { Andersen et al., } \\
2002\end{array}$ \\
\hline L.chinensis & Northeast South & Onion, cucumber, pumpkin & $\begin{array}{l}\text { Andersen et al., } \\
2002\end{array}$ \\
\hline L. trifolii & Northeast South & Leaf mustard, lettuce & $\begin{array}{l}\text { Tran, } 2000 ; \mathrm{Ha}, \\
2001\end{array}$ \\
\hline L. bryoniae & Red River Delta & Mung bean & Grimstad, 2004 \\
\hline
\end{tabular}

species. Native parasitoids play an important role in the suppression of leafminer populations (Saito et al., 1995).

Very few surveys for parasitoid fauna of leafminers has been conducted in Vietnam. The first documented parasitoid composition of leafminers, in general, was reported by Thang (1999). Eleven species of parasitoids associated with leafminers in vegetable crops were listed. Because of the great geographical distance, climatic and crop habitat difference, it is suspected that a large difference in native parasitoid fauna exists within Vietnam. The objectives of this study were to survey and identify the naturally occurring parasitoids of Liriomyza spp. in commercial field vegetable crops of several ecological regions of Vietnam, and also to evaluate the importance of different species as biological control agents in vegetable IPM programs.

\section{MATERIALS AND METHODS}

Field survey of parasitoids was conducted in 45 selected municipalities identified for large areas planted to vegetable crops of twenty provinces of central and southern regions of Vietnam, e.g. Thanh Hoa, Thua Thien Hue in the north central coast region, Quang Nam in the south central coast region, Kon Tum, Gia Lai and Dac Nong in the central highland region, Lam Dong, Tay Ninh, Binh Phuoc, Binh Duong and Ho Chi Minh City in the northeast south region, Dong Thap, An Giang, Tien Giang, Ben Tre, Kien Giang, Hau Giang, Soc Trang, Bac Lieu and $\mathrm{Ca} \mathrm{Mau}$ in the Mekong river delta region, from November 2003 to July 2004. Samples were taken from vegetables, including Japanese bunching onion (Allium fistulosum L.), leaf mustard (Brassica juncea (L.) Czern.), eggplant (Solanum melongena. L.), tomato
(Lycopersicon esculentum Mill), luffa (Luffa acutangula Roxb.), melons (Cucumis melo L.), cucumber (Cucumis sativas L.), yard-long bean (Vigna unguiculata (L.) Walp), bitter melon (Momordica charantia L.), Chinese squash (Cucurbita moschata (Butternut)), green bean (Phaseolus aureus Roxb.), French bean (Phaseolus vulgaris L.) and chrysanthemum greens (Chrysanthemum coronarium L.).

The insects were collected by hatching wasps from leafminer infested leaves of different vegetable crops. Leafminer infested leaves were randomly collected from vegetable commercial fields and placed in plastic bags labeled with the name of crop, location, date, and collector name(s). Samples were placed in an ice chest and brought into the laboratory.

After clearing other insects and residues, samples were singly placed in petri disks ( $9 \mathrm{~cm}$ in diameter) with filter paper. Samples were maintained at room temperature and daily supplied some drops of water for keeping humidity. The infested leaves were checked daily for parasitoid emergence. The number of adult parasitoids was recorded upon emergence. All parasitoids were kept in small grass vials with $70 \%$ ethanol. Parasitoids of the family Eulophidae and Eucophidae were identified by the third author with help of Dr. Kazuaki Kamijo (Bibai, Hokkaido, Japan), and parasitoids of the family Braconidae were identified by Dr. Kaoru Maeto (Laboratory of Insect Science, Faculty of Agriculture, Kobe University, Japan).

\section{RESULTS}

\section{Parasitoid species complex}

A total of 1862 parasitoid individuals emerged from leafminer infested vegetable leaves collected, and 18 
Table 2. Relative abundance of parasitoid species by family reared from infested vegetable leaves collected in Vietnam.

\begin{tabular}{lc}
\hline \multicolumn{1}{c}{ Parasitoid } & $\begin{array}{c}\text { Relative } \\
\text { abundance (\%) }\end{array}$ \\
\hline Baconidae & \\
Opius sp. & 0.2 \\
Opius chromatomyiae Belokobylskij & \\
$\quad$ \& Wharton & 3.1 \\
Ecoilidae & \\
Gronotoma sp. & 0.1 \\
Eulophidae & \\
Neochrysocharis okazakii Kamijo & 18.8 \\
Neochrysocharis formosa (Westwood) & 10.6 \\
Neochrysocharis beasleyi Fisher \& La Salle & 29.5 \\
Neochrysocharis sp. & 0.05 \\
Hemiptarsenus variconis (Girault) & 8.8 \\
Diglyphus isaea (Walker) & 8.9 \\
Cirrospilus ambiguous Hansson \& LaSalle & 1.5 \\
Chrysocharis pentheus (Walker) & 5.1 \\
Asecodes delucchii (Boucek) & 13.1 \\
Asecodes erxias (Walker) & 0.05 \\
Quadrastichus sp. & 0.2 \\
Pnigalio sp. & 0.05 \\
Stenomesius sp. & 0.05 \\
Closterocerus sp. & 0.05 \\
Closterocerus trifasciatus Westwood & 0.05 \\
\hline Total no. of emerged adults (N) & 1862 \\
\hline
\end{tabular}

parasitoid species of 3 families (Braconodae, Eucoilidae and Eulophidae) were identified (Table 2). Among them, Neochrysocharis beasleyi Fisher \& La Salle, $N$. okazakii, Acecodes delucchii (Boucek) and $N$. formosa were abundant species, accounting for $29.5 \%$, $18.8 \%, 13.1 \%$ and $10.6 \%$, respectively, of the total parasitoid adults that emerged. Neochrysocharis sp. is an additional species of the genus from Vietnam, existing on yard long bean in Thanh Hoa province, but was not abundant species.

\section{Parasitoid-host plant relationship}

Parasitoid species and the proportion of each species reared from the leafminer infested leaves varied with host plants (Table 3). A total of 10, 9, 7, 7, 6 and 5 species of parasitoid were recorded as natural enemies of Liriomyza spp. on leaf mustard, yard-long bean, tomato, casaba melon, French been and onion, respectively.

Within a given crop, the major parasitoids have been found. The most frequent parasitoid species reared from the leafminers on onion, leaf mustard and casaba melon was $N$. okazakii. While $N$. beasleyi was the most abundant species of leafminers on tomato and yard-long bean, this species was also the second most abundant on French bean. Neochrysocharis formosa was the second abundant species of the leafminers on onion, tomato

Table 3. Relative abundance (\%) of parasitoids reared from leafminer infested leaves of various vegetable crops in Vietnam (be continued)

\begin{tabular}{|c|c|c|c|c|}
\hline \multirow{2}{*}{ Crop } & \multirow{2}{*}{ Location } & \multicolumn{3}{|c|}{ Parasitoids } \\
\hline & & Species & Relative abundance & $\begin{array}{c}\text { Total No of } \\
\text { emerged adults }\end{array}$ \\
\hline \multirow[t]{5}{*}{ Onion } & Thanh Hoa, & Neochrysocharis okazakii & 92.5 & 108 \\
\hline & Thua Thien Hue & Neochrysocharis fomosa & 2.7 & \\
\hline & Quang Nam & Diglypus isaea & 2.7 & \\
\hline & and Lam Dong & Hemiptarsenus variconis & 0.9 & \\
\hline & & Cirrospilus ambiguus & 0.9 & \\
\hline \multirow[t]{10}{*}{ Leaf mustard } & Thanh Hoa, & Neochrysocharis okazakii & 50.9 & 216 \\
\hline & Thua Thien Hue, & Hemiptarsenus variconis & 31 & \\
\hline & Quang Nam, & Neochrysocharis fomosa & 8.3 & \\
\hline & Ca Mau & Neochrysocharis beasleyi & 4.6 & \\
\hline & and Bac Lieu & Quadrastichus sp. & 1.4 & \\
\hline & & Cirrospilus ambiguus & 0.9 & \\
\hline & & Chrysocharis pentheus & 0.9 & \\
\hline & & Asecodes delucchii & 0.9 & \\
\hline & & Gronotoma sp. & 0.5 & \\
\hline & & Opius chromatomyiae & 0.5 & \\
\hline \multirow[t]{7}{*}{ Tomato } & Quang Nam, Thua & Neochrysocharis beasleyi & 60.3 & 252 \\
\hline & Thien Hue, Kon Tum, & Neochrysocharis formosa & 17.9 & \\
\hline & Gia Lai, Lam Dong, & Asecodes delucchii & 10.3 & \\
\hline & Ho Chi Minh City, & Chrysocharis pentheus & 7.9 & \\
\hline & Binh Duong, Ben & Hemiptarsenus varinonis & 2.4 & \\
\hline & Tre, Kien Giang and & Opius sp. & 0.8 & \\
\hline & Bac Lieu & Neochrysocharis okazakii & 0.4 & \\
\hline \multirow[t]{7}{*}{ Casaba melon } & Thua Thien Hue and & Neochrysocharis okazakii & 49.5 & 204 \\
\hline & Quang Nam, & Hemiptarsenus variconis & 24.5 & \\
\hline & & Neochrysocharis formosa & 19.1 & \\
\hline & & Chrysocharis pentheus & 3.4 & \\
\hline & & Asecodes delucchii & 2.5 & \\
\hline & & Quadrastichus sp. & 0.5 & \\
\hline & & Gronotoma sp. & 0.5 & \\
\hline
\end{tabular}


Table 3. Relative abundance (\%) of parasitoids reared from leafminer infested leaves of various vegetable crops in Vietnam (continued)

\begin{tabular}{|c|c|c|c|c|}
\hline \multirow{2}{*}{ Crop } & \multirow{2}{*}{ Location } & \multicolumn{3}{|c|}{ Parasitoids } \\
\hline & & Species & Relative abundance & $\begin{array}{c}\text { Total No of } \\
\text { emerged adults }\end{array}$ \\
\hline \multirow[t]{9}{*}{ Yard-long bean } & Thanh Hoa, Tay & Neochrysocharis beasleyi & 53.9 & 308 \\
\hline & Ninh, Ho Chi Minh & Neochrysocharis fomosa & 21.4 & \\
\hline & City Kien Giang, Bac & Asecodes delucchii & 15.6 & \\
\hline & Lieu, Dong Thap and & Neochrysocharis okazakii & 3.9 & \\
\hline & $\mathrm{Ca} \mathrm{Mau}$ & Cirrospilus ambiguus & 2.3 & \\
\hline & & Hemiptarsenus variconis & 1.9 & \\
\hline & & Neochrysocharis sp. & 0.3 & \\
\hline & & Chrysocharis pentheus & 0.3 & \\
\hline & & Asecodes erxias & 0.3 & \\
\hline \multirow[t]{6}{*}{ French bean } & Kon Tum, Ho Chi & Asecodes delucchii & 52.6 & 249 \\
\hline & Minh City, Binh & Neochrysocharis beasleyi & 36.9 & \\
\hline & Duong, Hau Giang, & Cirrospilus ambiguus & 3.6 & \\
\hline & Tien Giang and Soc & Chrysocharis pentheus & 3.2 & \\
\hline & Trang & Hemiptarsenus variconis & 3.2 & \\
\hline & & Opius sp. & 0.4 & \\
\hline
\end{tabular}

and yard-long bean. Asecodes delucchii was the most abundant species on French bean, and the third most abundant species in yard-long bean. Hemiptarsenus varicoris existed on every host plant, and was the second most major species on leaf mustard and casaba melon.

\section{DISCUSSION}

More than 40 parasitoid species have been reared from the major leafminer species world-wide (Watehouse and Norriss, 1987). Our extensive survey revealed a relatively small parasitoid complex (18 species) among 14 vegetable crops in five agro-ecological regions across Vietnam. Most of the parasitoids found in this investigation were in family Eulophinidae. Among them, $N$. beasleyi, $N$. okazakii, $N$. formosa, $A$. delucchii, $D$. isaea, $H$. varicoris, and $C$. pentheus were predominated. This result is consistent with research in Japan and Vietnam in which $N$. fomosa, $N$. okazakii, C. pentheus and $H$. varicomis were found to be predominant in the open field plants (Saito et al., 1996; Arakaki and Kinjo, 1998; Thang, 1999). Previous research also indicated $N$. beasleyi and A. delucchii were the most abundant parasitoid species of $L$. sativae on cucumber in Hochiminh City (Tran et al., 2005). Thus, these species appear to be the most important candidate as biological control agents of Liriomyza spp.

In the present study, no investigation was done in the northern Vietnam. A previous study reported a total of 12 parasitoid species associating with Liriomyza leafminers in vegetable crops in the northern regions (Thang, 1999). Ha (2003) reported Quadrastichus liriomyzae (Hansson \& LaSalle), Diglyphus pusztensis Erodös and Dacnusa sibirica Telenga associating with L. sativae on French bean in North Vietnam. These species were not encountered in central and southern Vietnam in the present investigation.
Although many parasitoid species are polyphagous, attacking several dipterous leafminer species, some are strongly influenced by the host plant of vegetable crops (Murphy and LaSalle, 1999). The abundant parasitoids reared from Liriomyza species differed largely among crops (Table 3). The first and second most numerous parasitoids associated with Liriomyza species in tomato and yard-long bean were $N$. beasleyi and $N$. formosa. Neochrysocharis sp. A of Konishi (2004) was a different species from beasleyi, and N. sp. B of Konishi (2004) was beasleyi. Neochrysocharis beasleyi was described from Indonesia and Vietnam (Fisher and LaSalle, 2005) While numerous studies in Japan indicated $N$. formosa was predominated and has been recognized as an effective biological control agents of leafminers in tomato, bean and eggplants (Saito et al., 1996; Arakaki and Kinjo, 1998, Ohno et al., 1999; Mariana, 2000), the present study shows the first record of a predominance of $N$. beasley $i$ among leafminer parasitoid complex on tomato and yard-long bean in Vietnam. Among the parasitoid complex of the leafmiers on onion, leaf mustard and casaba melon, $N$. okazakii was predominant. Since a main leafminer attacking onion crops in Vietnam is L. chinensis, $N$. okazakii seems to be a good candidate as biological control of the leafminer. The most common parasitoid reared from French bean foliage was $A$. delucchii. This species was a Palaearctic parasitoid found recently in Southeast Asia (Joshi, 2001), and become the second most abundant parasitoid species of $L$. sativae in Ho Chi Minh region (Tran et al., 2005), and the third most abundant parasitoid of Liriomyza spp. on yard long bean. In Japan, $A$. delucchii was recorded associating with $L$. trifollii in bean (Arakaki and Kinjo, 1998). Thus, the plant species belonging the family of Fabaceae seem to be preferred by $A$. delucchii. Since host plants can affect on development and behavior of parasitoid species (Arthur 1962; Hare and Luck, 1991; Powell and Wright, 1992; Shukla 
and Tripathi, 1993), the distribution of parasitoid species and their abundance could vary among vegetable crops (Zehnder and Trumble, 1984; Johnson and Hara, 1987).

Previous studies indicated that among Liriomyza species established in Vietnam, $L$. sativae was clearly a dominant species found on a variety of vegetables, while $L$. bryoniea and $L$. trifolii were relatively new invasive species (Table 1). Although it may appear that some parasitoid species can be specific, there is little concrete evidence that Liriomyza parasitoids display any high degree of host specificity (Murphy and LaSalle, 1999; Chen et al., 2003). Since native polyphagous parasitoids of $L$. chinensis have quickly adopted a newly introduced L. sativae in Hangzhou, China (Chen et al., 2003), the species complex and abundance of these parasitoids on different vegetable crops in different agro-ecological regions could be of a fundamental importance for development of biological control strategies for any Liriomyza species.

\section{ACKNOWLEDGEMENTS}

We thank Dr. Kazuaki Kamijo (Bibai, Hokkaido, Japan) and Dr. Kaoru Maeto (Laboratory of Insect Science, Faculty of Agriculture, Kobe University, Japan) for their help with identification of parasitoids. We also thank to Mrs. N. T. Lan (Hongduc University, Vietnam), Mrs. L. T. T. Lam (Nonglam University, Vietnam), and the numerous Vietnamese officers of Plant Protection Departments for their assistance in the fields and the laboratory. We extend our thanks to our farmer cooperators for their assistance and collaboration on survey making in their fields. We gratefully acknowledge the critical comments by Dr. Takatoshi Ueno (Institute of Biological Control, Faculty of Agriculture, Kyushu University, Japan) to an earlier version of this manuscript. This work was supported in part by a Grand-in-Aid from the Japanese Society for the Promotion of Science and Technology (No. 15208007).

\section{REFERENCES}

Andersen, A., E. Nordhus, V. T. Thang, T. T. T. An, H. Q. Hung and T. Hofsvang 2002 Polyphagous Liriomyza species (Diptera: Agromyzidae) in vegetables in Vietnam. Trop. Agric. (Trinidad) 79. 241-246

Arakaki, N. and K. Kinjo 1988 Notes on the parasitoid fauna of the serpentine leafminer Liriomyza trifolii (Burgess) (Diptera: Agromyzidae) in Okinawa, southern Japan. Appl. Entomol. Zool. 33. 577-581

Arthur, A. P. 1962 Influence of host tree of Itoplectis conquisitor (Say) (Hymenoptera: Ichneumonidae), a polyphagous parasite of the European pine shoot moth Rhyacionia buoliana (Schiff) (Lepidoptera: Olethreutidae). Can. Entomol. 94. 337-347

Berit, S. 2001 Biology and management of Liriomyza sativae Blanchard (Diptera: Agromyzidae) in longbean in Vietnam. MSc thesis, The Agricultural University of Norway and The Norwegian Crop Research Institute

Chen, X. X., X. Y. Lang, Z. H. Xu, J. H. He and Y. Ma 2003 The occurrence of leafminers and their parasitoids on vegetables and weeds in Hangzhou area, Southeast China. BioControl
48. $515-527$

Fisher, N. and J. LaSalle 2005 A new species of Neochrysocharis Kurdjumov (Hymenoptera: Eulophidae), a parasitoid of serpentine leafminers (Diptera: Agromyzidae) in Southeast Asia. Zootaxa 1044. 27-34

Grimstad, K, B. 2004 The vegetable leafminer Liriomyza sativae (Diptera: Agromyzidae) and its parasitoid complex in mung beans in northern Vietnam. MSc thesis, The Agricultural University of Norway and The Norwegian Crop Research Institute

Ha, Q. H. 2001 Study of leafminers in vegetables and beans in Hanoi and surrounding. Vietnamese J. Plant Protect. 3. 10-14 (in Vietnamese with English summary)

Ha, Q. H. 2003 Morphological and biological characteristics of Quadrastichus liriomyzae Hansson (Hymemoptera: Eulophidae) parasitizing the leafminer Liriomyza sativae Blanchard (Diptera: Agromyzidae) on French bean in Hanoi region. In "Biological Control and Integrated Pest Management (IPM) in Vegetables in Vietnam". Proceedings, Vietnamese Norwegian Workshop, Hanoi 17- 18 October 2002. Planteforsk, Grønn Kunnskap 7. 43-46

Hare, J. D. and R. F. Luck 1991 Indirect effects of citrus cultivars on life history parameters of a parasitic wasp. Ecology $\mathbf{7 2}$. 1576-1585

Johansen, N. S., M. T. Tao, T. K. O. Le and E. Nordhus 2003 Susceptibility of Liriomyza sativae (Diptera: Agromyzidae) larvae to some insecticides scheduled for their control in North Vietnam. Grønn kunnskap 7. 157-165

Johnson, M. W. and A. H. Hara 1987 Influence of host crop on parasitoids (Hymenoptera) of Liriomyza spp. (Diptera: Agromyzidae). Environ. Entomol. 16. 339-344

Joshi, R. C. 2001 Philippines home to leafminer parasitoids. Biocontrol News and Information 22.60N

Konishi, K. 1998 An illustrated key to the Hymenoptera parasitoids of Liriomyza trifolii in Japan. Misc. Publ. Agro-Environ. Sci. 22. 27-76 (in Japanese)

Konishi, K. 2004 An illustrated key to the species of heminopterous parasitoids of leafmining agromyzid pests. In "Biological Control of Agricultural Pests in Asia-Theory and Practic", Asian Science Seminar, Fukuoka, Japan 12-22 October. JASS' 04, pp. 40-56

LaSalle, J. 1999 The problem and management of agromyzid leafminers on vegetables in Malaysia. In "Proceedings of a Workshop on Leafminers of Vegetables in Southeast Asia", ed by Lim, G. S., S. S. Soetikno and W. H. Loke, Serdang, Malaysia, CAB International, Southeast Asia Regional Centre, pp. $36-41$

Mariana, N. 2000 Studies on the ecological aspects of Neochrysocharis formosa (Hymenoptera: Eulophidae) attacking Liriomyza trifolii (Diptera: Agromyzidae). $\mathrm{PhD}$ thesis, Kyushu University, Japan

Minkenberg, O. P. J. M. 1990 On seasonal inoculative biological control. PhD thesis, Wageningen Agricultural University, The Netherlands

Murphy, S. T. and J. LaSalle 1999 Balancing biological control strategies in the IPM of New World invasive Liriomyza leafminers in field vegetable crops. Biocontrol News and Information 20. 91-104

Oatman, E. R. and G. G. Kenidy 1976 Methomyl induced outbreak of Liriomyza sativae on tomato. J. Econ. Entomol. 69. 667-668

Ohno, K., T. Ohmori and H. Takenmoto 1999 Effect of insecticides applications and indigenous parasitoids on population trends of Liriomyza trifolii in gerbera greenhouses. Jpn. J. Appl. Entomol. Zool. 43. 81-86 (in Japanese with English summary)

Parrella, M. P 1987 Biology of Liriomyza. Annu. Rev. Entomol. 32. 201-224

Powell, W. and A. F. Wright 1992 The influence of host food plants on host recognition by four aphiidine parasitoids (Hymenoptera: Barconidae). Bull. Entomol. Res. 81. $449-453$ 
Rauf, A., B. M. Shepard and M. W. Johnson 2000 Leafminers in vegetables, ornamental plants and weeds in Indonesia: survey of host crops, species composition and parasitoids. Inter. $J$. Pest Manage. 46. 257-266

Saito, T., A. Ozawa and F. Ikeda 1995 The evaluation of two imported hymenopteran parasites as biological control agents for the serpentine leafminer, Liriomyza trifolii (Burgess). Pro. Kanto-Tosan Plant Protec. Soc. 42. 235-237 (in Japanese with English summary)

Saito, T., F. Ikeda and A. Ozawa 1996 Effect of pesticides on parasitoid complex of serpentine leafminer Liriomyza trifolii (Burgess) in Shizuoka Prefecture. Jpn. J. Appl. Entomol. Zool. 40. 127-133 (in Japanese with English summary)

Shukla, A. N. and C. P. M. Tripathi 1993 Effect of food plant on the offspring sex ratio of Diaretiella rapae (Hymenoptera: Aphididae), a parasitoid of Lipaphis erysimi Kalt (Homoptera: Aphididae). Biol. Agric. Hortic. 9. 137-146

Spencer, K. A. 1973 Agromyzidae (Diptera) of economic importance. The Hague, Netherlands; Dr W. Junk

Thang, V. T. 1999 Surveys of leafminers (Liriomyza) and their parasitoids on vegetable in Vietnam 1998. In "Proceedings of a Workshop on Leafminers of Vegetables in-Southeast Asia", ed by Lim, G. S., S. S. Soetikno and W. H. Loke, Serdang, Malaysia, CAB International, Southeast Asia Regional Centre, pp. 36-41

Tran, D. H. and M. Takagi 2005 Susceptibility of the stone leek leafminer Liriomyza chinensis (Diptera: Agromyzidae) to insecticides. J. Fac. Agr., Kyushu Univ. 50. 183-390

Tran, T. T. A. 2000 Some preliminary results of study on leafminer, Liriomyza trifolii. Vietnamese J. Plant Protect. 2. 8-13 (in Vietnamese with English summary)

Tran, T. T. A., D. H. Tran, K. Konishi and M. Takagi 2005 The vegetable leafminer Liriomyza sativae Blanchard (Diptera: Agromyzidae) and its parasitoids on cucumber in the Ho Chi Minh region of Vietnam. J. Fac. Agr. Kyushu Univ. 50. $119-124$

Waterhouse, D. F., K. R. Norris 1987 Liriomyza species (Diptera: Agromyzidae) leafminers. In "Biological control: Pacific prospects", ed. Waterhouse, D. F. and K. R. Norris, Inkata Press, Melbourne, Australia, pp. 159-176

Zehnder, G. W. and J. T. Trumble 1984 Host selection of Liriomyza species (Diptera: Agromyzidae) and associated parasites in adjacent planting of tomato and celery. Environ. Entomol. 13. 492-496 